\title{
Microcommunities of algae on a Sphagnum mat
}

\author{
Celia A. Hooper
}

Hooper, C. A. 1981. Microcommunities of algae on a Sphagnum mat. - Holarct. Ecol. 4: 201-207.

The algal epiphytes of three species of Sphagnum from the mat edge of an acid bog were quantitatively sampled over three months. On the basis of differences in total algal abundance, algal diversity, and the growth of certain algal species and species groups, two significantly different algal communities were recognized. While these communities were only centimeters apart, they differed in physical, biological and nutrient parameters, with lower, moister plots having more algae, higher algal diversity, and lower concentrations of phosphate, ammonium, and silicate ions.

C. A. Hooper, Div. of Biological Sciences, Univ. of Michigan, Ann Arbor, MI 48109, USA.

\section{Introduction}

In 1976, Gough and Woelkerling described a technique for collecting "Aufwuchs" or assemblages of epiphytic algae and applied it to compare the epiphyton of several substrate plants. They showed that species abundances differ for algae that live on different macrophytes collected from different bog types. Other workers have analyzed the algal community on Sphagnum but few of these studies have been quantitative. Compère (1966), for example, found differences in the algal community on Sphagnum which were related to moisture conditions, but gave no details on how the algae were collected, the numbers of algae, what constitutes a significantly different community, or how moisture conditions were measured. Perhaps the most interesting recent work with the algal community on Sphagnum, however, has been done by Basilier and Granhall (1978) and Granhall and Selander (1973) and concerns nitrogenfixing algae. Generally, where blue-green, heterocystous epiphytes or endophytes occur on Sphagnum, nitrogen fixation by the algae is significant and potentially important to nutrient-poor bogs, though recently Basilier (1979) questioned the significance of algal fixation in temperate poor fen habitats. Basilier and Granhall (1978) have stressed the need for "the development of a practical method for quantifying algal colonization on the mosses."
It is unfortunate that the quantitative techniques of Gough and Woelkerling have not been more widely applied because the algal populations on Sphagnum are comparatively stable and are not subject to rates of sinking, water movement, and predation which may completely change a planktonic algal population overnight. In addition, the chemical and physical nature of the community can be manipulated and changes in the algae can be detected in weeks. These features make the community ideal for experimental ecology.

Another unresolved question in these studies concerns scale, or the minimum area over which differences in the algal populations can be detected. Woelkerling (1976) discusses the algal community of Sphagnum as if the whole bog were a homogenous entity. Other workers recognized microsites within bogs. These microsites may relate to drainage and bog micro-relief (Granhall and Selander 1973, Flensburg and Sparling 1973) or species of Sphagnum (Compère 1966), but unfortunately none of these workers quantify changes in the algal populations, discuss the ecological parameters of these algae, or discuss the scale over which the algae in these microsites may differ. These issues must be addressed before one can define and start to understand the dynamics of algal communities on Sphagnum.

In this study I have systematically applied the quantitative techniques of Gough and Woelkerling (1976) to

Accepted 4 December 1980

(c) HOLARCTIC ECOLOGY 0105-9327/81/030201-07 \$02.50/0 
plots on a bog mat edge. I looked at small areas and, using measurements of the distribution, abundance, and diversity of algae, attempted to determine whether these areas were substrates for discrete algal communities.

\section{Materials and methods}

Observations were made at North Gate Bog, a small kettlehole acid bog in Gogebic County, Michigan described by Montroy (1973) and Koenings (1976). Plots were laid out within a small $\left(15 \mathrm{~m}^{2}\right)$ area of the mat edge approximately $1.5 \mathrm{~m}$ from the open water of the bog lake. In 1978, 14 plots, $0.5 \times 0.5 \mathrm{~m}$, were used. In 1979,18 triangular plots, $25 \mathrm{~cm}$ on a side were laid out. Observations presented in this paper concern 1979 data from six of these plots. The other plots were used for experiments beyond the scope of this paper. The triangular plots were of two types which I will refer to as "Low" plots and "High" plots. Low plots were situated on spots where there was water visible between the moss plants. The measured average depth from the top of the tallest moss to the water table on 5 July was $4 \mathrm{~cm}$. These plots were dominated by Sphagnum cuspidatum and Sphagnum recurvum. Low plots were an average of $15 \mathrm{~cm}$ closer to the edge of the pond than were the high plots. The high plots were dominated by Sphagnum recurvum and Sphagnum magellanicum. There was no visible water on these plots over the course of the summer. The measured average distance from the tallest moss to the water table on 5 July was $7.5 \mathrm{~cm}$.

At the end of May, all plots received $250 \mathrm{ml}$ of mixed bog water. This water was obtained from the bog pond, from mat water, and from moss squeezings from several species of Sphagnum from several places in the bog. The algae in this water, while numerically insignificant relative to the numbers of cells indigenous to the plots, insured that the absence of a species from a given plot was probably not attributable to the absence of parent cells. Two of the high plots were sprayed with $250 \mathrm{ml}$ of distilled water every three days throughout the entire summer. These will be referred to as "watered plots". These plots were sprayed with distilled water to test what effect increased moisture might have on the algal community of the high plots.

During June, July, and August of 1978 and 1979, algae were collected monthly and sampled using the technique described in Gough and Woelkerling (1976). This procedure consisted of placing the substrate (Sphagnum) in a jar, covering it with washing solution, shaking the jar vigorously, and decanting the algae through cheesecloth. The washing procedure was repeated, the volume of the washing solution recorded, and the algae counted in well-mixed subsamples of this solution. Finally, the original Sphagnum sample was dried, and the number of cells was adjusted for solution volume and dry weight of the substrate. All numbers of algal cells will be expressed as cells per milligram dry weight of Sphagnum. The only deviation from the procedure of Gough and Woelkerling was the use of water rather than FAA as a washing solution. I preferred to examine the algae alive and found in a comparative test that there was no significant difference in the numbers of algae removed by these two solutions. Algae were identified with the aid of Prescott (1962), Bourrelly (1966), and Compère (1966).

Water samples were collected from the plots on the same dates that algae were sampled. Water was collected and filtered in the field using an Antlia Pneumatic Hand Pump (Schleicher and Schuell, Inc., Keene, New Hampshire 03431) fitted with glass microfiber paper (GF/F, Whatman Ltd., England). Water was pre-filtered by a coarse nylon mesh screen over the end of the collection tubing. The standing water from the low plots was readily drawn up from several spots on the plots. On the high plots, the mosses were parted slightly and the end of the collection tubing pressed down until water could be drawn. Several spots were sampled on these plots also.

Water samples were analyzed for three important algal nutrients: ammonium, phosphate, and silicate. All analyses followed methods in Strickland and Parsons (1972). Ammonium was determined by the phenol-hypochlorite method of Solorzano (1969). Ortho-phosphate was measured using the acid molybdate method of Murphy and Riley (1962). Reactive silicate analysis followed Strickland and Parsons' modification of the Mullin and Riley (1955) technique. Chemical analyses were started within two hours of field filtration.

In addition to algal observations at North Gate Bog, I looked at vertical zonation of algae on a uniform lawn of Sphagnum recurvum from an adjacent closed bog. By 'closed bog' I refer to a bog with no expanse of open water, or an entirely closed mat. For these experiments I collected some moss from a $1-\mathrm{m}^{2}$ area. I divided the plants into three samples and then, with scissors, snipped each sample into three portions: capitula (terminal branch clusters), the top $2.5 \mathrm{~cm}$ just below the capitula, and bottom portions. Bottom segments were an average of $10 \mathrm{~cm}$ in length. These divisions were chosen because they reflected distinctive natural partitions of the Sphagnum plants. The top $2.5 \mathrm{~cm}$ segments in the area grew vertically while the bottom portions were horizontal, covered by the vertical portions of neighboring plants. Algae were removed and sampled as described above.

\section{Results \\ Diversity}

Diversity was measured by two parameters: $S$, the number of species; and $\mathrm{H}^{\prime}$, the Shannon-Wiener diversity index, defined in Tab. 1. 
Tab. 1. Diversity of algae on Low and high plots. See Methods for explanation of plot types.

\begin{tabular}{lccc}
\hline Plot type & $\begin{array}{c}\text { Average number } \\
\text { of species, S }\end{array}$ & $\begin{array}{c}\text { Ave. } \\
\text { Shannon- } \\
\text { Wiener } \mathrm{H}^{\prime *}\end{array}$ & $\begin{array}{c}\text { Average } \\
\text { equitability }\end{array}$ \\
\hline Low plots & $25.5 \pm 4.5$ & 3.34 & 0.71 \\
High plots & $17.4 \pm 3.0$ & 2.73 & 0.66 \\
\hline
\end{tabular}

${ }^{*} \mathrm{H}^{\prime}=-\sum_{\mathrm{i}=1}^{\mathrm{S}} \mathrm{Pi}\left(\log _{2} \mathrm{Pi}\right), \mathrm{Pi}=$ Proportion of the total cells

belonging to the ith species.

The numbers of species present on the two plot types are shown in Tab. 1. The average number of species for low plots over the course of the summer was 25.5 , while high plots averaged only 17.4 species. One cannot assume that there is a normal distribution of the number of species on plots; therefore I used a non-parametric Wilcoxon Rank Sum Test (Siegel 1956) for a comparison of the difference between low and high plots, and found it significant at the 0.01 -level.

The Shannon-Wiener Index $\left(\mathrm{H}^{\prime}\right)$ combines the number of species with the equitability of the numbers of cells in each species. A community with high diversity has many species and little numerical dominance by any species. The maximum value for $\mathrm{H}^{\prime}$ is $\log _{2} \mathrm{~S}-\max$ where $S-\max$ is the total number of species. Based on all 1978 observations, in which 72 species were counted, the maximum possible $\mathrm{H}^{\prime}$ would be 6.21 bits.

As shown in Tab. 1, low plots had higher average values for $\mathrm{H}^{\prime}$. A Wilcoxon Rank Sum Test of the significance of this difference shows that it is significant at the 0.05 -level. The equitability component of the Index was somewhat greater for low plots, but this difference was not statistically significant.

While I found that the diversity of algae was significantly greater on low plots, this finding must be taken with a grain of salt. Several authors have pointed out that diversity may be related to sample size (Kaesler et al. 1978) and this applies to my data. Low plot substrates had more algae per unit area and, in an attempt to equalize algal density on the counting slide, less moss and more washing water was used for low plot substrates. In spite of these precautions, the average number of cells observed for low plots was 367 , while an average of 195 cells were examined for the high plots. Diversity of algae (both $\mathrm{S}$ and $\mathrm{H}^{\prime}$ ) shows a correlation with both total algae per gram dry weight Sphagnum and numbers of cells observed, as is shown by a Spearman Rank correlation coefficient (Siegel 1956) of 0.55 for cells observed and $\mathrm{H}^{\prime}$, and $\mathbf{0 . 6 2}$ for algae per gram dry weight and $\mathrm{H}^{\prime}$. Some of this correlation is attributable to the differences in sample size, but there also appears to be a real association between algal density and diversity in these microhabitats.
Tab. 2. Average total algae on low and high plots in cells per milligram dry weight Sphagnum. For definitions of plot types, see Methods. $\mathrm{N}=18$. Standard deviations for Low plots, $\mathrm{s}=$ 798; for High plots, $s=243$; for Watered plots, $s=109$.

\begin{tabular}{lrrr}
\hline Plot type & Jun & Jul & Aug \\
\hline Low plots $\ldots \ldots \ldots \ldots \ldots \ldots \ldots$ & 1737 & 1049 & 1306 \\
High plots $\ldots \ldots \ldots \ldots \ldots \ldots$ & 787 & 444 & 354 \\
Watered plots $\ldots \ldots \ldots \ldots \ldots$ & 650 & 464 & 452 \\
\hline
\end{tabular}

\section{Total numbers of algae}

In addition to having greater species diversity, low plots had an average of 2.5 times as many total algal cells as high plots. This is shown in Tab. 2. If the data are log-normalized, the difference in total algae between low and high plots is significant at the 0.025-level.

The high plots that received distilled water are not different from the unsprayed high plots in average total number of algae although the variance was significantly lower on the watered plots. These plots were similar also in diversity $(S=19.2 \pm 5.0$ for watered plots; $S=$ $15.8 \pm 9.4$ for unwatered plots) and the abundance of many species and species groups. For this reason the watered and unwatered high plots are considered together in all other analyses.

\section{Abundances of species and species groups}

Figs 1 and 2 show the monthly average abundances of some of the algae commonly occurring on the plots. As would be expected for the organisms in two different microhabitats, the algae growing on the two plot types showed several distribution patterns. Some algae were abundant on both plot types, while some occurred predominantly on either low or high plots.

Cylindrocystis brebisonii, a desmid, was the most abundant species of algae. It was common throughout the summer and was present on both plot types. While it

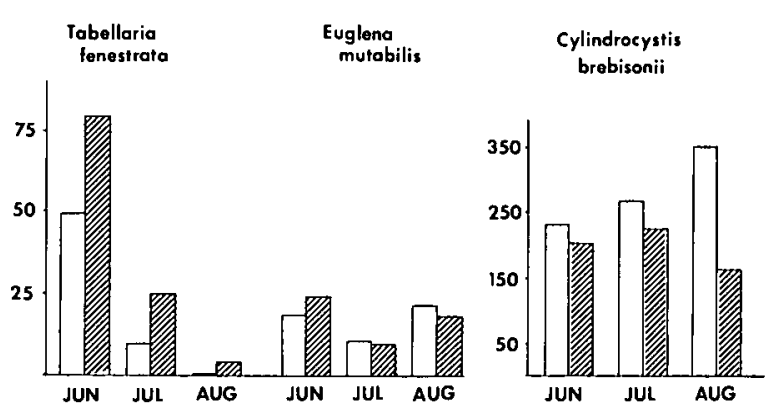

Fig. 1. Monthly average abundance of three algal species in cells per mg dry weight Sphagnum. Open bars represent low plots; hatched bars represent high plots. Plot types are explained in Methods. 


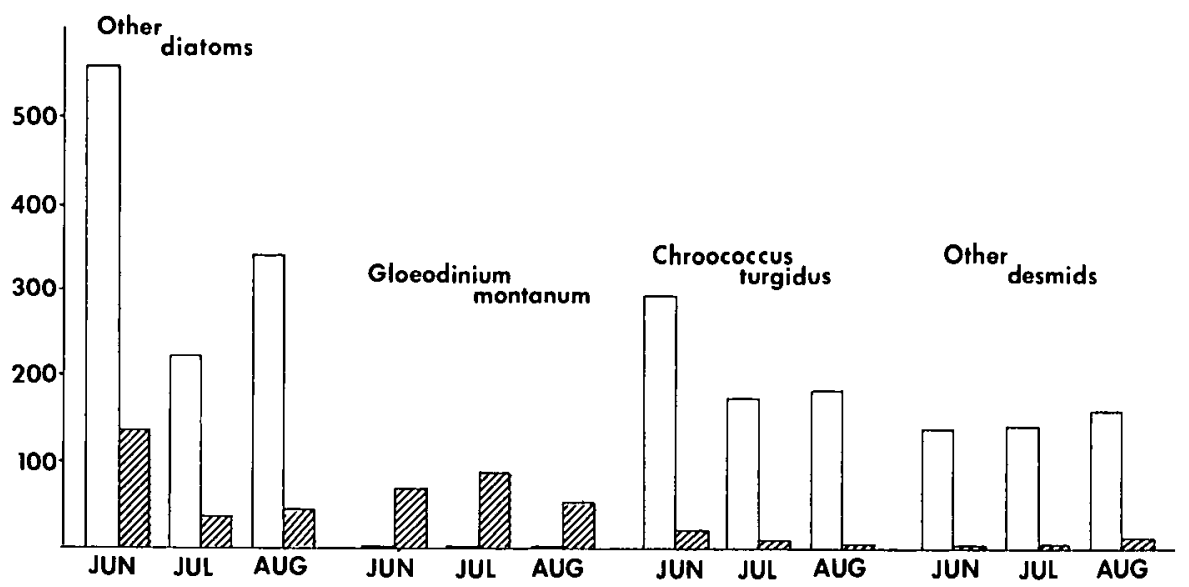

Fig. 2. Monthly average abundances of Chroococcus turgidus; desmids other than Cylindrocystis; diatoms other than Tabellaria; and Gloeodinium montanum in cells per mg dry weight Sphagnum. Open bars represent low plots; hatched bars represent high plots.

was somewhat more common on the low plots, the difference in abundance was not significant.

Tabellaria fenestrata, a diatom, was somewhat more abundant on high plots than on low plots, but again this difference was not significant. Tabellaria declined steadily over the ocourse of the summer on both plot types. This diatom is more commonly found as an epiphyte on branches or objects that project out into the open water of ponds than on the semiaquatic surface of Sphagnum plants.

Euglena mutabilis was virtually identical in abundance on both plot types, but like Tabellaria was never a dominant species in these natural communities.

Chroococcus turgidus was very abundant on the low plots throughout the summer, but was significantly less abundant on the high plots.

"Other Desmids" includes all species of desmids other than Cylindrocystis. Like Chroococcus, the desmids are significantly more abundant on the low plots during all months of the summer.

"Other Diatoms" includes all diatoms except Tabellaria. As shown in Fig. 2, these algae are more abundant on low plots than on high plots. However, some of the diatoms (especially a small species of Frustulia) show a marked clumped distribution that confers high variance to the data.

Gloeodinium montanum is an encysted dinoflagellate. This alga is vertually never found on the low plots, but is common on the high plots.

By August, 14 species were found only on low plots. Four species were found exclusively on high plots. Twenty species were present on both plot types, but of these, six species had much larger populations on one plot type than on the other.

\section{Nutrients}

Low plots had lower concentrations of all nutrients measured at all times. This is shown in Tab. 3. Analysis of variance (Remington and Shork 1970) reveals that the differences in silicate between the low and high plots are significant at the 0.025 -level.

An argument can be made for the exclusion of a couple values from the nutrient data collected in July. On the sampling day there were signs that deer had been on and around the plots, and two plots showed extraordinarily high levels of phosphate and ammonia, with no silicate increases. These two plots, one a high plot and one a low plot, had concentrations of ammonia 3.4 and 4.5 times higher than the averages for their respective plot types. The high plot had a phosphate concentration 6.2 times the average for high plot phosphate, while the low plot had a concentration twice as high as average. The variance introduced into the data by these two July measurements overwhelms the significance of the differences in phosphate and ammonia levels on the low and high plots. If these four values are excluded, however, analysis of variance reveals that the nutrient differences between low and high plots are highly significant $(p<0.005)$.

Tab. 3. Concentrations of nutrients in mat interstitial water $\left(\mu \mathrm{Mol} \mathrm{I}^{-1}\right)$. See Methods for explanation of plot types.

\begin{tabular}{lllll}
\hline Nutrient & Plot type & Jun & Jul & Aug \\
\hline $\mathrm{PO}_{4}$ & Low & 0.33 & 0.80 & 0.60 \\
$\mathrm{PO}_{4}$ & High & 1.18 & 2.95 & 1.10 \\
$\mathrm{NH}_{4}$ & Low & 1.05 & 5.58 & 2.05 \\
$\mathrm{NH}_{4}$ & High & 3.40 & 7.48 & 3.48 \\
$\mathrm{Si}$ & Low & 3.08 & 6.63 & 5.10 \\
$\mathrm{Si}$ & High & 6.56 & 11.59 & 8.13 \\
\hline
\end{tabular}




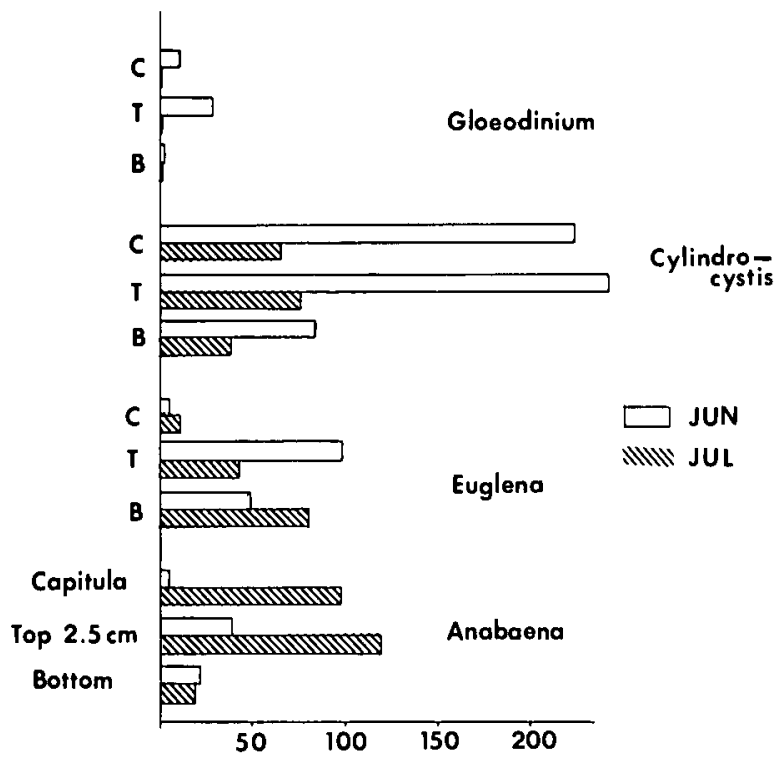

Fig. 3. Vertical distribution of Gloeodinium montanum, Cylindrocystis brebisonii, Euglena mutabilis, and Anabaena minutissima over the capitulum, top $2.5 \mathrm{~cm}$ and lower portions of $S$. recurvum during June and July. Numbers in cells per $\mathrm{mg}$ dry weight Sphagnum.

\section{Vertical distribution of algae}

The total algae collected on capitula, upper $2.5-\mathrm{cm}$ and bottom portions of Sphagnum recurvum from an adjacent bog showed no significant differences between June and July when they were sampled. Similarly, there are no highly significant differences in the total number of cells for the different segment types. If the data are normalized by a log transformation, however, the upper $2.5-\mathrm{cm}$ portions are slightly significantly higher in total algal abundance than the capitula and lower portions.

There are more significant differences, however, if we look at single species and species groups. Five representative species or groups are shown in Fig. 3. With the exception of blue-green species, most algae decrease in abundance from June to July. The extreme of this trend was exhibited by Gloeodinium montanum which was entirely absent in July from all moss segments. Several species showed differential reductions in the numbers of cells in the different moss layers. Cylindrocystis brebisonii, the most abundant alga, decreased in cell numbers more in the upper two layers than in the lower portions of the moss. Euglena mutabilis decreased $42 \%$ from the top $2.5-\mathrm{cm}$ layer where it was most common in June; however, these motile algae actually increased and became most abundant in the bottom portions in July, suggesting they may have actually migrated to the moister location. Compère (1966) also suggests flagellated algae use their motility to escape periodic droughts.

As is shown in Fig. 3, capitula had fewer blue-green algae, as exemplified by Anabaena minutissima, than did the lower sections of the moss. This was also noted by Basilier and Granhall (1978).

In general, the algae in the closed bog were less abundant, less diverse and more like the "high plot" rather than the "low plot" algae in North Gate Bog.

\section{Discussion}

The large plots constructed on the mat edge of North Gate Bog in 1978 were laid out in a way that I hoped would minimize variations in conditions like light, temperature, moisture, and moss density. Close examination revealed however that the algal community on these plots was not homogeneous and some plots had lower, wetter areas on ends nearest the open water of the bog lake. Thus, in 1979 I laid out two types of plots so that I could test the null hypothesis that there was no difference in the algal community on low and high plots. The plots differed by only a few centimeters in height above the water table and proximity to the open water, and were similar in most other respects, and so the null hypothesis was reasonable.

However, monthly algal counts forced me to reject this null hypothesis. The low plots had significantly more algal epiphytes on the Sphagnum plants. In addition, the algae were more diverse on the low plots, using either numbers of species or the Shannon-Wiener Diversity Index as a measure of diversity.

Of the two measures of diversity, $\mathrm{S}$, the number of species, seems to serve as well as $\mathrm{H}^{\prime}$, the Shannon-Wiener Index. Because $S$ is a factor of $\mathrm{H}^{\prime}$, the two measures are correlated. For data from my plots, $\mathrm{H}^{\prime}$ was always more strongly correlated with $S$ than with $J$, the evenness component of $\mathrm{H}^{\prime}$. Thus this algal community contrasts with the plankton communities of Sager and Hasler (1969) where $\mathrm{H}^{\prime}$ was more strongly correlated with J. Also, S correlated more strongly with the number of cells observed than did $\mathrm{H}^{\prime}$. In addition to supporting the greater utility of $\mathrm{S}$ over $\mathrm{H}^{\prime}$, this relationship suggests that some of the difference in diversity between low and high plots may in part be due to differences in the number of cells observed for low and high plots.

The varying patterns of distribution of species and species groups also support the idea that low and high plots differed. The patterns certainly suggest the algal community is different. By August, most species showed significant differences in the sizes of populations on the two plot types. The most common alga, Cylindrocystis brebisonii, however, appears to be a generalist and was abundant on both plot types. The high plots were especially depauperate in Chroococcus turgidus and desmids. My data indirectly support the findings of Woelkerling (1976) who found greater desmid abundance and diversity in bogs with some open water rather than in bogs with entirely closed mats. The observations I made on an adjacent closed bog revealed 
that the algae there were more similar to high plot algae.

Given the varying patterns of algal abundance on these two plot types, we might next want to discover which abiotic and biotic factors most strongly affect the algal populations and distinguish the two plot types.

The analysis of the vertical distribution of algae suggests that moisture conditions might be important since some algae moved to or did not decrease as much in the moist lower layers of moss in July as the closed bog dried out. But simply increasing the moisture on some high plots in the open bog did not significantly change the average numbers of algae present, although over the course of the summer these plots received better than $10 \mathrm{~cm}$ more water than the other high plots. The average precipitation for the area during June, July, and August is $31.5 \mathrm{~cm}$ (Mich. Dept. of Agriculture 1971). Watering did not increase the average number of algae on the high plots, but the treatment did lower the variance in this number, and did slightly increase the number of species present. While these effects are minor relative to the natural differences between low and high plots, one may conclude that such changes in water availability may have subtle effects on the behavior and growth of individual species.

The low and high plots also differed in the quality of the water most immediately available. The concentrations of three dissolved nutrients were all higher on high plots. This difference raises more questions. The low nutrient concentrations on the low plots are most likely a result rather than a cause of high algal productivity, but other factors, such as moss nutrient uptake and cation exchange capacity, as well as the nutrient inputs to these two areas must also play a part. The finding of lower concentrations of phosphate where there are greater numbers of algae seems to contradict observations of Basilier (1979) and Basilier and Granhall (1978) who found greater rates of algal nitrogen fixation and approximate algal abundance in minerotrophic mire habitats where total phosphorous is in higher concentration. The studies are not directly comparable, however, as I measured total algal abundance rather than just blue-green algae, and as I only measured dissolved inorganic phosphate, rather than total phosphorus. In addition, Basilier (1979) did not collect the water for phosphorus analysis at the same time as the other measurements were made. Given the differences in these reports, however, and the finding by Lehman (1979) that algal populations may quickly and dynamically alter the nutrient concentrations in a lake, closer study of the nutrient-algal relationships in the bog mat would be desirable. I am now analyzing data from plots that were artificially enriched with nitrogen, phosphate and other nutrients. These data may elucidate whether dissolved nutrients are a key to the algal community on Sphagnum, or whether other factors such as species of Sphagnum, algal dispersal, predation, or the abundance of nitrogen-fixing algae are more important.

Acknowledgements - I wish to thank Drs. C. Yocum, H. Crum, D. Lane, B. Rathke, L. Nilsson, and two anonymous reviewers for their comments on the manuscript. My work was supported by Rackham Dissertation and Sigma Xi grants, and by the facilities of the Division of Biological Sciences and the School of Natural Resources at the Univ. of Michigan. Finally, I wish to thank Dr. R. E. Gordon and the Univ. of Notre Dame for permission to perform my studies on their property.

\section{References}

Basilier, K. 1979. Moss-associated nitrogen fixation in some mire and coniferous forest environments around Uppsala, Sweden. - Lindbergia 5: 84-88.

- and Granhall, U. 1978. Nitrogen fixation in wet minerotrophic moss communities of a subarctic mire. - Oikos 31 : 236-46.

Bourrelly, P. 1966. Les algues d'eau douce, Tome I, II, et III. Éditions N. Boubée, Paris.

Compère, P., 1966. Observations sur les algues des groupments a sphaignes des hautes-fagnes de Belgique. - Bull. Jard. bot. État. Brux. 36: 5-51.

Flensburg, T. and Sparling, J. H. 1973. The algal microflora of a string mire in relation to the chemical composition of the water. - Can. J. Bot. 51: 743-49.

Gough, S., and Woelkerling, W. 1976. On the removal and quantification of algal aufwuchs from macrophyte hosts. Hydrobiologia. 48: 203.

Granhall, U. and Selander, H. 1973. Nitrogen fixation in a subarctic mire. - Oikos 24: 8-15.

Kaesler, R., Herricks, E., and Crossman, J. 1978. Use of indices of diversity and hierarchical diversity in stream surveys. - In: Dickson, Cairns, and Livingston (ed.), Biological data in Water pollution assessment. Amer. Soc. for Testing and Materials, Easton, MD.

Koenings, J., 1976. In situ experiments on the dissolved and colloidal state of iron in an acid bog lake. - Limnol. Oceanogr. 21: 674-683.

Lehman, J. 1979. Physical and chemical factors affecting the seasonal abundance of Asterionella formosa in a small temperate lake. - Arch. Hydrobiol. 87: 274-303.

Michigan Department of Agriculture, 1971. Climate of Michigan by stations. Michigan Weather Service, East Lansing, Michigan.

Montroy, L. 1973. Experimental manipulation of bog plankton communities. Ph.D. thesis, Univ. of Notre Dame, South Bend, Indiana.

Mullin, J. and Riley, J. 1955. The colorimetric determination of silicate with special reference to sea and natural waters. - Analytica Chim. Acta 12: 162-175.

Murphy, J. and Riley, J. 1962. A modified single solution method for the determination of phosphate in natural waters. - Analytica Chim. Acta 27: 31-36.

Prescott, G. 1962. Algae of the western Great Lakes area, revised ed. - Wm. C. Brown Co. Dubuque, lowa.

Remington, R. and Shork, M. 1970. Statistics with applications ot the biological and health sciences. - Prentice-Hall, Englewood Cliffs, New Jersey.

Sager, P. and Hasler, A. 1969. Species diversity in lacustrine phytoplankton I. The components of the index of diversity from Shannon's formula. - Am. Nat. 103: 51-60.

Siegel, S. 1956. Nonparametric statistics. - McGraw-Hill, New York. 
Solorzano, L. 1969. Determination of ammonia in natural waters by the phenolhypochlorite method. - Limnol. Oceanogr. 14: 799-801.

Strickland, J. D. H. and Parsons, T. 1972. A practical handbook of seawater analysis. - Fish. Res. Bd Canada, Bull. 167, Ottawa.
Woelkerling, W. 1976. Aufwuchs and plankton communities of selected acid bogs, alkaline bogs, and closed bogs. Hydrobiologia 48: 209 . 
This document is a scanned copy of a printed document. No warranty is given about the accuracy of the copy. Users should refer to the original published version of the material. 